\title{
HUBUNGAN PERSEPSI SISWA MENGENAI IKLIM KELAS DENGAN ORIENTASI TUJUAN SISWA DENGAN MENGONTROL SELF-EFFICACY (Penelitian pada Siswa SMP Madania Bogor)
}

\author{
M. Nanang Suprayogi \\ Jurusan Psikologi, Fakultas Psikologi, Bina Nusantara University \\ Jln. Kemanggisan Ilir III, No 45, Kemanggisan, Palmerah, Jakarta Barat 11480 \\ nang578@yahoo.com
}

\begin{abstract}
This research is to test variable relations of student's perception about class climate with student orientation variables to be self-efficacy variable as a controller variable. There are four types of purpose orientation, that are task orientation, self-enhancing ego orientation, self-defeating ego orientation, and work avoidance orientation. Each purpose orientation will direct students into specific learning behavior that will determine their learning result. The subjects of this research will be students in SMP Madania Bogor. This research uses calculation of partial correlation, double regression, and t-test.
\end{abstract}

Keywords: purpose-oriented, students perception, self-efficacy, class climate, partial correlation

\begin{abstract}
ABSTRAK
Penelitian ini bertujuan untuk menguji hubungan variabel persepsi siswa mengenai iklim kelas dengan variabel orientasi tujuan siswa dengan menjadikan variabel self-efficacy sebagai variabel pengontrol. Ada empat tipe dari orientasi tujuan. Yaitu orientasi task, orientasi ego self-enhancing, orientasi ego self-defeating, dan orientasi work avoidance. Masing-masing orientasi tujuan tersebut akan mengarahkan siswa kepada perilaku belajar tertentu yang akan menentukan hasil dari belajar siswa. Subjek pada penelitian ini adalah siswa SMP Madania Bogor. Penelitian ini menggunakan penghitungan korelasi parsial, regresi ganda dan ttest.
\end{abstract}

Kata kunci: orientasi tujuan, persepsi siswa, self-efficacy, iklim kelas, korelasi parsial 


\section{PENDAHULUAN}

Semua lembaga pendidikan menghendaki tercapainya tujuan pendidikan, diantaranya adalah tercapainya prestasi belajar siswa karena mereka mengadopsi orientasi tujuan yang positif. Siswa dengan orientasi tujuan yang positif akan mengarahkan segala daya dan upayanya untuk mengikuti kegiatan belajar mengajar dengan sepenuhnya, hal ini akan mengantarkan siswa untuk mencapai prestasi belajar yang optimal.

\section{Pengertian Orientasi Tujuan}

Stipek (2000) mengatakan bahwa orientasi tujuan bisa diartikan sebagai bagian dari faktor kognitif dalam motivasi yang menjadi penggerak bagi individu untuk mendekat atau menjauh dari suatu objek. Dengan demikian dapat dinyatakan bahwa orientasi tujuan merupakan faktor kognitif yang harus dimiliki oleh siswa. Orientasi tujuan ini mempengaruhi pemilihan aktivitas dalam tugastugas akademik dan pemilihan pendekatan belajar. Pendapat lain mengatakan bahwa orientasi tujuan diartikan sebagai arah pikiran yang tetap (Webster, 1990). Orientasi tujuan menurut Ames (dalam Pintrich \& Schunk, 1996) disebutkan sebagai: goal orientation represents an integrated pattern of beliefs that leads to different ways of approaching, engaging to achievement situation. Senada dengan apa yang dikemukakan oleh Ames di atas, Barron \& Harackiewicz (2001) menyatakan bahwa orientasi tujuan menjelaskan mengenai integrasi belief yang mengarah pada berbagai cara dalam merespon situasi berprestasi. Orientasi tujuan merupakan orientasi situasional spesifik yang mewakili keinginan untuk mengembangkan, mencapai, atau menunjukkan kompetensi. Hal ini dapat mempengaruhi cara siswa melakukan pendekatan dan menunjukkan hasil belajarnya, serta dapat mempengaruhi performa siswa di kelas (Harackiewicz et. al. 1997). Orientasi tujuan yang diadopsi seseorang dalam situasi prestatif akan mempengaruhi pikiran, afeksi dan prilaku seseorang (Jagacinski \& Duda, 2001).

Dalam penelitian ini yang dimaksud dengan orientasi tujuan adalah orientasi situasional spesifik yang mengarahkan siswa pada berbagai cara untuk merespon situasi berprestasi dan mewakili keinginan untuk mengembangkan, mencapai atau menunjukkan kompetensi, dimana hal ini dapat mempengaruhi pendekatan dan performa belajar siswa. Orientasi tujuan menurut Skaalvik (1997) dapat dibedakan dalam 4 jenis. Keempat jenis tersebut adalah: task orientation (orientasi tugas), self enhancing ego orientation (orientasi meningkatkan ego), self defeating ego orientation (orientasi memperlemah ego), dan yang terakhir work avoidance orientation (orientasi penghindaran).

Task Orientation. Nicholls, (dalam Skaalvik, 1997) mengatakan: "Task orientation means that the focus of attention is on the task rather than on some extrinsic reward" (p. 71). Ini berarti bahwa fokus dari perhatian siswa berada pada tugas, bukan pada hal-hal yang berada di luar tugas tesebut. Kegiatan belajar, memahami, memecahkan masalah, dan pengembangan ketrampilan baru akan bermuara pada kegiatan itu sendiri, belajar merupakan nilai yang inheren, penuh makna dan memuaskan. Duda dan Nicholls (dalam Skaalvik, 1997), menambahkan bahwa siswa dengan orientasi task cenderung melihat penguasaan sebagai usaha yang dependen.

Self-Enhancing Ego Orientation. Menurut Skaalvik (1997), self-enhancing ego orientation dideskripsikan sebagai berikut: "Self-enhancing ego orientation is defined by the goal of demonstrating superior abilities and outperforming other students" (p. 79). Jadi self-enhancing ego orientation dapat didefinisikan sebagai sebuah tujuan untuk mendemonstrasikan kemampuan superior dan mengalahkan perfomansi siswa lain.

Self-Defeating Ego Orientation. Menurut Skaalvik (1997), self-defeating ego orientation dideskripsikan sebagai berikut: "self-defeating ego orientation on other hand, is defined by the goal of avoiding looking stupid or being negatively judged by others" (p. 79). Jadi yang dimaksud dengan self-defeating ego orientation digambarkan sebagai tujuan untuk menghindari terlihat bodoh atau dinilai negatif oleh orang lain. 
Work Avoidance Orientation. Beberapa definisi dari orientasi penghindaran tugas sebagai berikut: “...represent a form of avoidance motivation" (Nicholls, dalam Meece \& Holt, 1993:582), "... has been associated with the most negative effects of learning” (Archer, 1994, dalam Elliot \& Harackiewicz et. al., 2000: 317), “...motivated to complete their work with minimal effort" (Harackiewicz et. al., 1997:1284). Dari deskripsi-deskripsi tersebut dapat disimpulkan bahwa orientasi penghindaran tugas berfokus pada keinginan untuk menghindari tugas-tugas akademik dan mengerjakan tugas dengan upaya yang minim. Orientasi ini memiliki efek yang paling negatif dalam belajar.

\section{Faktor-faktor yang Mempengaruhi Orientasi Tujuan}

Faktor-faktor yang dapat mempengaruhi orientasi tujuan dapat dibagi dalam faktor pribadi dan faktor lingkungan.

Faktor-faktor pribadi yang dapat mempengaruhi orientasi tujuan adalah 1). Penerimaan Tujuan. Erez dan Zidon (dalam Woolfolk, 2004) mengatakan bahwa jika siswa mau menetapkan tujuan ataupun mau menerima tujuan yang ditetapkan orang lain, motivasi belajar akan muncul. Namun sebaliknya jika siswa menolak menentukan tujuan maupun menolak untuk menerima tujuan yang ditetapkan orang lain, maka motivasi belajar tidak akan muncul. 2). Motivasi Berprestasi. Motif ini merupakan motif unidimensi untuk mencapai performa yang sangat baik. Motivasi berprestasi terdiri dari orientasi penguasaan tugas yang merupakan keinginan untuk bekerja keras, melakukan pekerjaan dengan baik dan memilih tugas yang menantang, dan sifat kompetitif (competitiveness) yaitu keinginan untuk berkompetisi dan lebih unggul dari pada orang lain.

Siswa yang memiliki sifat kompetitif tinggi akan mengadopsi orientasi ego, sedangkan siswa yang orientasinya berpusat pada tugas cenderung mengadopsi orientasi penguasaan dan menolak orientasi penghindaran tugas (Harackiewicz et. al., 1997). 3). Jenis Kelamin. Masih banyak pertentangan pendapat mengenai jenis kelamin mana yang cenderung mengadopsi orientasi tugas atau orientasi ego, sehingga penelitian mengenai hal ini masih perlu terus dilakukan (Pintrich \& Schunk, 1996). 4) Self-efficacy. Bandura (1994) menyatakan bahwa siswa yang memiliki self-efficacy yang tinggi cenderung menetapkan orientasi yang tinggi, tidak takut gagal, dan mampu bertahan ketika menemui kesulitan dalam menguasai tugas yang sedang dikerjakan. Sedangkan siswa yang memiliki self-efficacy rendah cenderung menetapkan orientasi yang rendah, dan cenderung menghindar dari tugas yang sulit serta cepat menyerah ketika menghadapi kesulitan.

Faktor-faktor lingkungan yang dapat mempengaruhi orientasi tujuan adalah 1) Orang Tua. Woolfolk, (2004); Locke dan Latham (dalam Pintrich \& Schunk, 1996) mengatakan bahwa harapan, aspirasi dan contoh dari orang tua akan mempengaruhi perkembangan orientasi tujuan anak. 2) Kelompok Etnik. Penelitian hal ini masih sedikit dilakukan, namun ditemukan adanya perbedaan orientasi tujuan dari kelompok etnik yang berbeda, dimana kelompok etnik minoritas memiliki orientasi tugas (Pintrich dan Schunk, 1996). 3) Iklim Kelas. Dalam Church, Elliot \& Gable (2001) disebutkan adanya enam area dari iklim kelas yang dapat mempengaruhi terbentuknya orientasi yang dimiliki siswa. Keenam hal tersebut pertama kali ditemukan oleh Ames (1992), yaitu tugas yang harus dikerjakan siswa (task), otonomi yang diberikan pada siswa ketika mereka sedang mengerjakan tugas (autonomy), pemberian penghargaan bagi prestasi siswa (recognition), pengorganisasian kelas sehingga siswa dapat saling bekerja sama dan berinteraksi (grouping), pelaksanaan evaluasi (evaluation) dan penggunaan waktu di kelas yang berkaitan dengan penentuan waktu penyelesaian tugas oleh siswa dan fleksibilitas jadwal kegiatan (time) dimana keenam hal ini disingkat TARGET. Solomon (1996) dari hasil penelitiannya menemukan bahwa persepsi terhadap iklim kelas yang mengarah pada penguasaan materi akan mendorong timbulnya usaha yang besar sehingga hal ini akan berpengaruh positif terhadap keberhasilan belajar. 


\section{Pengertian Self-efficacy}

Menurut Bandura (1986), self-efficacy adalah keyakinan individu akan kemampuannya untuk mengorganisasikan dan melakukan suatu tindakan yang diinginkan untuk meraih suatu kinerja yang direncanakan. Woolfolk (2004), mendefinisikan self-efficacy sebagai kepercayaan individu terhadap kemampuannya dalam menghadapi situasi tertentu. Sedangkan menurut Wilhite (1990), self-efficacy adalah kepercayaan atau keyakinan yang dimiliki individu untuk mengontrol hasil usahanya. Dalam hubungannya dengan proses belajar di sekolah, Thomas, Inventosch dan Rohwer (dalam Wilhite, 1990) mendefinisikan self-efficacy sebagai tingkat dimana siswa yakin bahwa mereka dapat mengontrol hasil belajarnya.

Dalam penelitian ini, self-efficacy didefinisikan sebagai keyakinan atau kepercayaan siswa terhadap kemampuannya untuk mengorganisasikan dan melakukan suatu tindakan untuk mencapai keberhasilan yang diharapkan. Bandura (1986) mengemukakan bahwa self-efficacy yang tinggi akan meningkatkan prestasi dan kesejahteraan pribadi seseorang melalui beberapa cara. Orang yang memiliki keyakinan yang tinggi terhadap kemampuannya akan memandang tugas yang sulit sebagai suatu tantangan yang harus dikuasai, bukan sebagai ancaman yang harus dihindari. Ia akan mengatur sendiri orientasi yang penuh tantangan dan mempertahankan komitmen yang kuat untuk dirinya. Seseorang juga akan mempertinggi dan meningkatkan usahanya dalam menghadapi kegagalan. Secara cepat pula akan memulihkan kembali self-efficacy-nya setelah mengalami kegagalan. Sebaliknya orang yang tidak yakin dengan kemampuannya akan menghindari tugas-tugas yang sulit yang dianggapnya merupakan ancaman bagi dirinya. Orang tersebut memiliki aspirasi yang rendah dan komitmen yang lemah terhadap orientasi yang ingin diraih. Manakala menghadapi tugas-tugas yang sulit, ia lebih memikirkan kekurangan yang dimiliki, halangan yang akan ditemui, dan hal-hal lain yang tidak memuaskan daripada berkonsentrasi agar kinerja berhasil dengan baik. Orang tersebut juga akan mengurangi usahanya dan cepat menyerah ketika menghadapi kesulitan. Ia lambat pula memulihkan kembali rasa self-efficacy yang mengikuti kegagalan karena memandang kinerja yang kurang sebagai kurangnya bakat.

Dengan demikian, tingkat self-efficacy siswa merupakan variabel yang penting untuk mengetahui prestasi yang diperolehnya didalam kelas karena self-efficacy yang tinggi akan meningkatkan kinerja siswa sehingga prestasi belajarnya menjadi lebih tinggi. Sebaliknya, selfefficacy yang rendah akan menurunkan kinerja siswa sehingga lambat laun pretasi belajar siswa juga akan menurun.

\section{Pengertian Persepsi Siswa Mengenai Iklim Kelas}

Chaplin (1999) mengatakan bahwa persepsi dapat diartikan sebagai suatu proses mengetahui atau mengenali objek dan kejadian kognitif dengan bantuan indra. Hal ini selaras dengan Matlin (2002) yang menyatakan bahwa persepsi merupakan penggunaan pengetahuan yang telah dimiliki untuk mengolah dan menginterpretasikan stimulus yang diterima oleh indera. Persepsi terhadap suatu objek dapat dijelaskan melalui teori pemrosesan dari bawah ke atas dan dari atas ke bawah (bottom-up - top-down processing). Dalam memproses suatu stimulus, seseorang akan mencatat stimulus dalam reseptor sensoris. Hadirnya stimulus akan menggerakkan proses pengenalan objek. Informasi yang diterima oleh reseptor sensoris akan 'bergerak' dari tingkat pengenalan yang paling rendah sampai ke tingkat yang lebih tinggi dalam korteks sehingga objek dapat dikenali. Bersamaan dengan terjadinya proses bottom-up terjadi juga proses top down. Proses ini menekankan bagaimana konsep yang sudah dimiliki seseorang dan proses mental tingkat tinggi mempengaruhi pengenalan objek. Dapat dikatakan bahwa konsep yang sudah dimiliki, harapan, dan ingatan akan membantu seseorang dalam mengidentifikasi suatu objek. Harapan ini terbentuk berdasarkan pengalaman di masa lalu. 
Persepsi terhadap stimulus akan berdampak terhadap berbagai hal. Dalam kaitannya dengan iklim kelas, guru merupakan objek yang sangat penting yang akan dipersepsi, yang pada akhirnya akan mempengaruhi orientasi tujuan siswa. Dari model-model pembelajaran yang dikemukakan oleh Ramsden (1992), Entwistle (1981), serta Cote \& Levine (2000) terlihat bahwa persepsi terhadap pengajar, lingkungan pembelajaran dan evaluasi merupakan hal yang mempengaruhi prestasi belajar secara tak langsung.

Dalam kaitannya dengan orientasi tujuan, siswa akan lebih berorientasi pada tugas jika mempersepsi bahwa materi yang dipelajari menarik dan bermanfaat dibandingkan jika ia mempersepsi bahwa materi tidak menarik dan tidak bermanfaat (Woolfolk, 2004). Orientasi belajar dapat dibentuk maupun diubah, tergantung dari lingkungan. Mengingat bahwa situasi kelas dapat membentuk orientasi tujuan siswa, guru berperan penting dalam memfasilitasi pengadopsian orientasi tujuan siswa (Woolfolk, 2004; Pintrich \& Schunk, 1996). Metode pengajaran guru yang bersifat pemusatan terhadap siswa, yaitu pengajaran yang menjadikan peserta didik sebagai pusat perhatian, adanya harapan tinggi dari guru terhadap siswa, guru mendorong perserta didik untuk berpikir sendiri, berusaha mengorganisasi materi yang telah diberikan, dan terciptanya situasi pembelajaran yang menyenangkan akan mendorong terbentuknya orientasi tugas. Sebaliknya cara pengajaran yang berpusat pada guru, yaitu pengajaran dimana guru tidak menjadikan siswa sebagai pusat perhatian, tidak memiliki harapan tinggi terhadap siswa, tidak mendorong siswa untuk berpikir secara mandiri, tidak mendorong siswa untuk mengorganisasikan materi yang telah diberikan, dan tidak mendorong terciptanya situasi pembelajaran yang menyenangkan akan mendorong pengadopsian orientasi ego (McCombs \& Whisler, 1997).

Persepsi yang positif terhadap pengajaran akan membuat siswa merasakan kesenangan dalam belajar, mendorong mereka untuk mempelajari materi lebih mendalam, dan pada akhirnya dapat membuat siswa lebih terlibat dalam proses belajar mengajar (Church, Elliot \& Gable, 2001). Hal-hal yang dihasilkan oleh persepsi positif terhadap pengajaran yang telah disebutkan di atas berkaitan dengan ciri-ciri yang ada pada orientasi task. Dengan demikian, dapat dikatakan bahwa persepsi yang positif terhadap pengajaran akan mendorong timbulnya keterlibatan terhadap tugas-tugas sekolah yang harus dikerjakan, dan pada akhirnya akan mempengaruhi terbentuknya orientasi task. Sebaliknya menurut Church et. al., (2001) persepsi pengajaran yang positif ini tidak berkaitan dengan orientasi ego karena dalam orientasi ego yang dipentingkan adalah mendapatkan nilai yang baik dan performa yang lebih baik dari pada orang lain, dan bukanlah penguasaan dan keterlibatan yang mendalam terhadap materi. Persepsi terhadap pengajaran juga tidak berkaitan dengan orientasi penghindaran tugas, karena siswa dengan orientasi ini tidak mempedulikan hal-hal yang terjadi di kelas, termasuk pengajaran yang diberikan guru.

Selanjutnya faktor evaluasi sangat menentukan perilaku belajar siswa, karena pandangan mengenai evaluasi yang diberikan oleh guru akan mempengaruhi pendekatan belajar yang dipilih melalui orientasi yang diadposi. Jika siswa menganggap evaluasi yang akan diberikan hanya menuntut pendekatan belajar permukaan seperti soal-soal yang bersifat hafalan saja, hal ini akan mendorong pengadopsian orientasi ego. Sebaliknya jika siswa menganggap evaluasi yang akan diberikan menuntut pemahaman yang mendalam dan memerlukan pendekatan belajar mendalam, hal ini akan mendorong pengadopsian orientasi task (Church, Elliot \& Gable, 2001).

Faktor evaluasi berkaitan dengan situasi kelas yang terbentuk karena jenis evaluasi yang diberikan. Jika evaluasi menekankan pada perbandingan kemampuan kognitif secara sosial, siswa akan mengadopsi orientasi ego dan orientasi work avoidance. Sebaliknya, jika evaluasi menekankan pada peningkatan diri, partisipasi, usaha dan pendekatan belajar efektif dari peserta didik, siswa akan mengadopsi orientasi task (Ames \& Archer, 1998). Dalam penelitian ini persepsi mengenai iklim kelas merupakan persepsi yang dimiliki siswa terhadap pembelajaran, dalam hal ini pengajaran guru dan situasi belajar mengajar, serta evaluasi yang diberikan guru. 
Kedua faktor yakni self-efficacy dan persepsi siswa mengenai iklim kelas merupakan faktor yang memberi pengaruh terhadap orientasi tujuan siswa dalam mengikuti kegiatan belajar mengajar. Mengingat orientasi tujuan yang dimiliki siswa akan mempengaruhi usaha dan kesungguhan yang dikeluarkan oleh siswa dalam mengikuti kegitan belajar mengajar, maka penting sekali kedua faktor tersebut untuk diteliti seberapa besar pengaruh keduanya terhadap orientasi tujuan siswa di sekolah.

\section{Definisi Operasional Variabel}

Untuk menjelaskan pengertian dari variabel-variabel yang terlibat dalam hipotesis penelitian ini, maka dirumuskan definisi operasional setiap variabel yaitu orientasi tujuan siswa, self-efficacy, dan persepsi siswa mengenai iklim kelas.

Orientasi tujuan siswa adalah orientasi situasional spesifik yang mengarahkan siswa pada berbagai cara untuk merespon situasi berprestasi dan mewakili keinginan untuk mengembangkan, mencapai atau menunjukkan kompetensi, dimana hal ini dapat mempengaruhi pendekatan dan performa belajar siswa. Orientasi tujuan siswa dioperasionalkan sebagai penilaian siswa tentang orientasi tujuan yang diukur melalui jawaban subjek pada kuesioner orientasi tujuan siswa.

Self-efficacy adalah keyakinan atau kepercayaan siswa terhadap kemampuannya untuk mengorganisasikan dan melakukan suatu tindakan yang diinginkan untuk mencapai keberhasilan yang diharapkan. Self-efficacy dioperasionalkan sebagai skor pada skala yang mengukur keyakinan siswa akan kemampuan diri dan berprestasi di sekolah. Semakin tinggi skor yang diperoleh semakin tinggi self-efficacy yang dimiliki.

Persepsi siswa mengenai iklim kelas adalah interpretasi siswa akan hal-hal yang diterimanya di kelas, yang meliputi cara pengajaran guru, situasi belajar mengajar, dan evaluasi yang diberikan guru yang secara tidak langsung mempengaruhi orientasi belajarnya. Persepsi siswa mengenai iklim kelas dioperasionalkan sebagai gambaran penilaian dari siswa mengenai iklim kelas yang diukur melalui jawaban subjek pada kuesioner persepsi mengenai iklim kelas. Semakin tinggi skor yang dihasilkan dari kuesioner tersebut, maka diasumsikan semakin baik persepsi iklim kelas yang dirasakan siswa.

\section{METODOLOGI PENELITIAN}

\section{Populasi dan Sampel Penelitian}

Dalam penelitian ini yang menjadi populasi adalah siswa-siswi SMP Madania. Adapun sampel penelitian dipilih siswa kelas 9 didasarkan atas pertimbangan bahwa siswa pada jenjang kelas 9 telah bersekolah di SMP Madania lebih lama dibandingkan dengan adik kelas mereka, sehingga mereka dianggap memiliki pengalaman lebih lama mengikuti kegiatan belajar di SMP Madania dan memiliki pengalaman lebih lama dalam merasakan iklim kelas di Sekolah Madania.

\section{Tehnik Pengambilan Sampel}

Tehnik pengambilan sampel yang digunakan dalam penelitian ini adalah tehnik purposive sampling. Pengambilan sampel dilakukan dengan menggunakan pertimbangan dan penilaian bahwa siswa kelas 9 Sekolah Madania merupakan sampel yang representatif dalam penelitian ini. Kelas 9 telah mengenyam pendidikan di sekolah Madania lebih lama dibandingkan dengan siswa kelas 7 dan siswa kelas 8. Mereka telah merasakan iklim kelas yang lebih lama dibandingkan dengan siswa lain. Dengan pengalamannya yang lebih lama ini mereka membentuk persepsinya terhadap iklim kelas. 
Persepsi mereka tersebut dapat memberikan gambaran tentang iklim kelas di sekolah Madania. Pengambilan sampel pada siswa kelas 9 juga dimaksudkan untuk memudahkan dalam penelitian, mengingat mereka berada dalam satu level jenjang pendidikan, sehingga memudahkan peneliti dan pihak sekolah dalam melakukan penjadwalan kegiatan penelitian.

\section{Instrumen Penelitian}

Instrumen penelitian dibagi menjadi tiga skala, yaitu skala orientasi tujuan, skala self-efficacy, dan skala persepsi siswa mengenai iklim kelas. Kuesioner ini disusun berdasarkan skala orientasi tujuan yang dikembangkan oleh Skaalvik (1997) yang telah dimodifikasi oleh peneliti, terdiri dari task orientation, self-enhancing ego orientation, self-defeating ego orientation, dan work avoidance orientation.

Pengukuran self-efficacy yang digunakan dalam penelitian ini disusun dengan mengacu pada aspek-aspek self-efficacy dari penelitian Bandura dan Wood dan Locke (dalam Maurer \& Pierce, 1998), yang kemudian diadaptasi dan dimodifikasi oleh peneliti. Item-item dalam pengukuran selfefficacy ini terdiri dari enam aspek self-efficacy, yaitu: kemampuan dalam konsentrasi, kemampuan dalam mengingat, kemampuan dalam pemahaman, kemampuan dalam menjelaskan, kemampuan dalam membedakan konsep, dan kemampuan dalam menyimpulkan masalah. Dalam penghitungan skala persepsi siswa mengenai iklim kelas, digunakan adaptasi dari instrumen Perceived Classroom Environment yang dikembangkan oleh Church, Elliot \& Gable (2001). Dalam Perceived Classroom Environment, Church dan kawan-kawan mengemukakan adanya 3 komponen yaitu keterlibatan terhadap proses belajar mengajar (lecture engagement), evaluasi yang ketat (harsh evaluation), serta fokus evaluasi (evaluation focus).

Ketiga kuesioner ini menggunakan model Likert dengan skala lima. Pada setiap item disediakan 5 pilihan jawaban yaitu: sangat sesuai (SS), sesuai (S), ragu-ragu (R), tidak sesuai (TS), dan sangat tidak sesuai (STS). Penilaian dilakukan dengan cara sebagai berikut, untuk pernyataan favorable pilihan jawaban yang sangat sesuai diberi nilai 5, sesuai diberi nilai 4, ragu-ragu diberi nilai 3 , tidak sesuai diberi nilai 2 , dan sangat tidak sesuai diberi nilai 1 . Adapun untuk pernyataan yang unfavorable dilakukan dengan cara sebaliknya.

\section{Uji Coba Instrumen}

Uji coba instrumen dilakukan untuk mengetahui validitas dan reliabilitas alat ukur apakah layak untuk digunakan pada penelitian ini. Melalui perhitungan analisis item dengan SPSS versi 11.5, diperoleh item-item yang dapat digunakan dalam penelitian ini. Berdasarkan hasil uji validitas dan reliabilitas didapatkan hasil seperti pada Tabel 1.

Tabel 1 Hasil Uji Validitas dan Reliabilitas Instrumen

\begin{tabular}{|c|c|c|c|c|c|}
\hline \multirow[t]{2}{*}{ Variabel } & \multirow{2}{*}{$\begin{array}{l}\text { Jumlah Item } \\
\text { Uji Coba }\end{array}$} & \multirow{2}{*}{$\begin{array}{l}\text { No Item } \\
\text { Gugur }\end{array}$} & \multicolumn{2}{|c|}{ Keofisien Alpha } & \multirow{2}{*}{$\begin{array}{l}\text { Total Item } \\
\text { Terpakai }\end{array}$} \\
\hline & & & $\begin{array}{l}\text { Sebelum } \\
\text { Gugur }\end{array}$ & $\begin{array}{l}\text { Sesudah } \\
\text { Gugur }\end{array}$ & \\
\hline Task orientation & 6 & 5 & 0.79 & 0.80 & 5 \\
\hline Self-enhancing ego orientation & 5 & 5 & 0.68 & 0.69 & 4 \\
\hline Self-defeating ego orientation & 7 & 2,7 & 0.62 & 0.64 & 5 \\
\hline Work avoidance orientation & 4 & - & 0.64 & 0.64 & 4 \\
\hline Self-efficacy & 14 & $2,6,8,11$ & 0.60 & 0.80 & 10 \\
\hline $\begin{array}{l}\text { Persepsi siswa terhadap iklim } \\
\text { kelas }\end{array}$ & 11 & $1,2,3,8$ & 0.65 & 0.79 & 7 \\
\hline
\end{tabular}


Instrumen yang telah diujicobakan kemudian peneliti susun kembali dan berikut adalah tabel hasil uji coba instrumen penelitian yang kemudian digunakan dalam penelitian.

Tabel 2 Skala Orientasi Tujuan, Self-Efficacy dan Persepsi Siswa Mengenai Iklim Kelas

\begin{tabular}{|c|c|c|c|c|c|}
\hline Orientasi Tujuan & $\begin{array}{l}\text { Jumlah } \\
\text { Item }\end{array}$ & Self-Efficacy & $\begin{array}{l}\text { Jumlah } \\
\text { Item }\end{array}$ & $\begin{array}{c}\text { Persepsi Siswa } \\
\text { Mengenai Iklim } \\
\text { Kelas } \\
\end{array}$ & $\begin{array}{c}\text { Jumlah } \\
\text { Item }\end{array}$ \\
\hline Task orientation & 5 & $\begin{array}{l}\text { Kemampuan dalam } \\
\text { konsentrasi }\end{array}$ & 2 & $\begin{array}{l}\text { Keterlibatan } \\
\text { terhadap proses } \\
\text { belajar mengajar }\end{array}$ & 1 \\
\hline $\begin{array}{l}\text { Self enhancing ego } \\
\text { orientation }\end{array}$ & 4 & $\begin{array}{l}\text { Kemampuan dalam } \\
\text { mengingat }\end{array}$ & 2 & $\begin{array}{l}\text { Evaluasi yang } \\
\text { ketat }\end{array}$ & 3 \\
\hline $\begin{array}{l}\text { Self defeating ego } \\
\text { orientation }\end{array}$ & 5 & $\begin{array}{l}\text { Kemampuan dalam } \\
\text { pemahaman }\end{array}$ & 1 & Fokus evaluasi & 3 \\
\hline \multirow[t]{3}{*}{$\begin{array}{l}\text { Work avoidance } \\
\text { orientation }\end{array}$} & 4 & $\begin{array}{l}\text { Kemampuan dalam } \\
\text { menjelaskan }\end{array}$ & 2 & & \\
\hline & & $\begin{array}{l}\text { Kemampuan dalam } \\
\text { membedakan konsep }\end{array}$ & 1 & & \\
\hline & & $\begin{array}{l}\text { Kemampuan dalam } \\
\text { menyimpulkan masalah }\end{array}$ & 2 & & \\
\hline Total item & 18 & Total Item & 10 & Total Item & 7 \\
\hline
\end{tabular}

\section{Metode Analisis Data}

Untuk menguji hipotesis penelitian yakni menguji hubungan antara variabel persepsi siswa mengenai iklim kelas dengan orientasi tujuan (task, ego self-enhancing, egi self-defeating, work avoidance) dengan mengontrol self-efficacy digunakan analisis korelasi parsial.

\section{HASIL DAN PEMBAHASAN}

\section{Gambaran Data Penelitian}

Tabel 3 menampilkan gambaran data statistik penelitian ini yang meliputi minimum, maksimum, mean, standar deviasi variabel-variabel penelitian dengan N sebanyak 101.

Tabel 3 Gambaran Data Penelitian

\begin{tabular}{lcccc}
\hline \multicolumn{1}{c}{ Variabel } & Min & Max & Mean & SD \\
\hline Self-Efficacy & 1.10 & 4.10 & 3.27 & 0.48 \\
Iklim Kelas & 1.29 & 5.00 & 2.91 & 0.69 \\
Task Orientation & 2.40 & 5.00 & 4.00 & 0.54 \\
Self-Enhancing Orientation & 2.50 & 5.00 & 3.84 & 0.59 \\
Self-Defeating Orientation & 1.80 & 5.00 & 3.31 & 0.61 \\
Work Avoidance Orientation & 1.75 & 5.00 & 3.68 & 0.81 \\
\hline
\end{tabular}

Dari tabel tersebut dapat dilihat bahwa nilai rata-rata mayoritas variabel penelitian berada diatas 3. Median teoritiknya adalah 3. Hal ini berarti rata-rata data sampel penelitian di atas median. Pada variabel self-efficacy nilai rata-rata sebesar 3.27. Hal ini berarti jawaban sampel penelitian berada pada angka 3 dengan 4, yaitu antara "ragu-ragu" dan "sesuai”. Sementara variabel self-enhancing 
berada pada nilai 3.84, variabel self-defeating pada nilai 3.31, dan variabel work avoidance pada nilai 3.68. Hal yang berbeda terlihat pada variabel persepsi siswa mengenai iklim kelas dan task orientation. Nilai rata-rata variabel persepsi siswa mengenai iklim kelas berada pada angka 2.91. Hal ini berarti rata-rata sampel penelitian berada pada jawaban "ragu-ragu". Sementara nilai rata-rata variabel task orientation pada angka 4.00, hal ini berarti rata-rata sampel penelitian berada pada jawaban di atas median.

Pada nilai standar deviasi dapat dilihat nilai variabel work avoidance berada pada nilai tertinggi, yaitu berada angka 0.81 , dan nilai variabel self-efficacy terendah, yaitu berada pada angka 0.48. Hal ini berarti jawaban responden pada varibel work avoidance lebih heterogen, sementara pada variabel self-efficacy lebih homogen.

\section{Analisis Data Penelitian}

Pengujian hipotesis penelitian ini secara langsung dilakukan dengan uji statistik korelasi parsial untuk melihat korelasi persepsi siswa mengenai iklim kelas sebagai variabel independen terhadap orientasi tujuan sebagai variabel dependen dengan self-efficacy sebagai variabel kontrol. Berikut ditampilkan tabel hasil korelasi parsial.

Tabel 4 Hasil Korelasi Parsial Persepsi Mengenai Iklim Kelas dengan Orientasi Tujuan dengan Mengontrol Self-Efficacy

\begin{tabular}{cccccccccc}
\hline & \multicolumn{8}{c}{ Korelasi Parsial } \\
\hline \multirow{2}{*}{$\begin{array}{c}\text { Persepsi } \\
\text { mengenai }\end{array}$} & \multicolumn{2}{c}{ Task } & \multicolumn{2}{c}{$\begin{array}{c}\text { Ego } \\
\text { self-enhancing }\end{array}$} & \multicolumn{2}{c}{$\begin{array}{c}\text { Ego } \\
\text { self-defeating }\end{array}$} & \multicolumn{2}{c}{ Work avoidance } \\
nyklim kelas & $\mathrm{p}$ & korelasi & $\mathrm{p}$ & korelasi & $\mathrm{p}$ & korelasi & $\mathrm{p}$ & korelasi \\
\cline { 2 - 10 } & 0.90 & -0.12 & 0.30 & 0.10 & 0.77 & -0.30 & 0.01 & -0.25
\end{tabular}

Keterangan : $\mathrm{p}=0.05$

Korelasi variabel persepsi mengenai iklim kelas, dan variabel orientasi task dengan mengontrol variabel self-efficacy. Perhitungan korelasi parsial dilakukan untuk menguji hubungan variabel persepsi mengenai iklim kelas terhadap orientasi task dengan mengontrol variabel selfefficacy. Dari hasil analisis diperoleh nilai korelasi sebesar -0.12 dengan $p=0.90$. $(p>0.05)$ Dengan demikian korelasi tidak signifikan. Dari penghitungan tersebut maka dapat disimpulkan bahwa tidak ada hubungan yang positif dan signifikan antara variabel persepsi mengenai iklim kelas dengan variabel orientasi task.

Korelasi variabel persepsi mengenai iklim kelas, dan variabel orientasi ego self-enhancing dengan mengontrol variabel self-efficacy. Kemudian dengan perhitungan korelasi parsial dilihat pula hubungan variabel persepsi mengenai iklim kelas dengan orientasi ego self-enhancing dengan mengontrol self-efficacy. Dari hasil analisis diperoleh nilai korelasi sebesar 0.10 dengan $p=0.30(p>$ 0.05). Dengan demikian korelasi tidak signifikan. Dari penghitungan tersebut maka dapat disimpulkan bahwa tidak ada hubungan yang positif dan signifikan antara variabel variabel persepsi mengenai iklim kelas dengan variabel orientasi ego self-enhancing.

Korelasi variabel persepsi mengenai iklim kelas, dan variabel orientasi ego self-defeating dengan mengontrol variabel Self-efficacy. Selanjutnya dilihat pula hubungan variabel persepsi mengenai iklim kelas dengan variabel orientasi ego self-defeating. Dari hasil analisis diperoleh nilai korelasi sebesar -0.30 dengan $p=0.77$. $(\mathrm{p}>0.05)$ Dengan demikian korelasi tidak signifikan. Dari penghitungan tersebut maka dapat disimpulkan bahwa ada tidak ada hubungan yang negatif dan signifikan antara variabel persepsi mengenai iklim kelas dengan variabel orientasi ego self-defeating. 
Korelasi variabel persepsi mengenai iklim kelas, dan variabel orientasi work avoidance dengan mengontrol variabel Self-efficacy. Penelitian ini melihat pula korelasi antara variabel persepsi mengenai iklim kelas terhadap variabel orientasi work avoidance dengan mengontrol self-efficacy. Dari hasil analisis diperoleh nilai korelasi sebesar -0.25 dengan $\mathrm{p}=0.01(\mathrm{p}<0.05)$. Dengan demikian korelasi signifikan. Dari penghitungan tersebut maka dapat disimpulkan bahwa ada hubungan yang negatif dan signifikan antara variabel persepsi mengenai iklim kelas dengan variabel orientasi work avoidance.

Pada penelitian ini juga dapat dilihat besaran sumbangan variabel persepsi siswa mengenai iklim kelas dan variabel self-efficacy terhadap variabel orientasi tujuan dengan menggunakan analisis regresi ganda. Data tersebut dapat dilihat pada tabel 5 berikut:

Tabel 5 Nilai Adjusted R Square

Variabel Persepsi Siswa Mengenai Iklim Kelas dan Variabel Self-Efficacy

\begin{tabular}{ccccc}
\hline \multirow{2}{*}{ Variabel } & Task & $\begin{array}{c}\text { Ego } \\
\text { self-enhancing }\end{array}$ & $\begin{array}{c}\text { Ego } \\
\text { self-defeating }\end{array}$ & $\begin{array}{c}\text { Work } \\
\text { avoidance }\end{array}$ \\
\cline { 2 - 5 } $\begin{array}{c}\text { Pesepsi Mengenai Iklim kelas } \\
\text { \& self-efficacy } \\
\text { Self-efficacy }\end{array}$ & 0.171 & 0.229 & -0.001 & 0.099 \\
& 0.179 & 0.228 & 0.008 & 0.099 \\
\hline
\end{tabular}

Dari data tersebut diketahui bahwa variabel yang paling berpengaruh terhadap variabel Orientasi adalah variabel self-efficacy.

Pada orientasi task diketahui nilai Adjusted $R$ Square sebesar 0.179. Hal ini berarti bahwa variabel self-efficacy menyumbang varians orientasi task sebesar $17.9 \%$. Pada orientasi ego selfenhancing diketahui nilai Adjusted $R$ Square sebesar 0.228. Hal ini berarti bahwa variabel self-efficacy menyumbang bagi orientasi ego self-enhancing sebesar $22.8 \%$. Sedangkan pada orientasi ego selfdefeating diketahui nilai Adjusted $R$ Square sebesar 0.008. Hal ini berarti bahwa variabel self-efficacy menyumbang bagi orientasi ego self-defeating sebesar $00.8 \%$. Sedangkan pada orientasi work avoidance diketahui nilai Adjusted $R$ Square sebesar 0.099. Hal ini berarti bahwa variabel self-efficacy dan variabel persepsi mengenai iklim kelas menyumbang bagi orientasi work avoidance sebesar $09.9 \%$.

Pada penelitian ini diketahui pula apakah terdapat perbedaan self-efficacy, persepsi mengenai iklim kelas dan orientasi task, orientasi ego self-enhancing, orientasi ego self-defeating dan orientasi work avoidance antara siswa laki-laki dan siswa perempuan SMP Madania. Untuk melihat perbedaan tersebut dilakukan penghitungan t-test. Hasil penghitungan masing-masing variabel terhadap kelompok laki-laki dan perempuan tersebut dapat dilihat pada Tabel 6 dengan penjelasan sebagai berikut:

Tabel 6 Hasil Uji T Variabel Self-Efficacy,

Persepsi Siswa mengenai Iklim Kelas dan Orientasi Tujuan

\begin{tabular}{ccccccc} 
Nilai P & Self- \\
$(2$ tailed $)$ & efficacy & $\begin{array}{c}\text { Persepsi siswa } \\
\text { mengenai iklim } \\
\text { kelas }\end{array}$ & Task & $\begin{array}{c}\text { Ego self- } \\
\text { enhancing }\end{array}$ & $\begin{array}{c}\text { Ego self- } \\
\text { defeating }\end{array}$ & $\begin{array}{c}\text { Work } \\
\text { avoidance }\end{array}$ \\
\hline 0.025 & 0.481 & 0.730 & 0.720 & 0.289 & 0.136 & 0.272 \\
\hline
\end{tabular}


Perbedaan self-efficacy, antara siswa laki-laki dan siswa perempuan SMP Madania. Dari hasil perhitungan t-test tersebut dapat dilihat bahwa nilai signifikansi variabel self-efficacy sebesar 0.481 (>0.025). Karena nilai signifikansi lebih besar dari taraf signifikasi 0.025, maka dapat diambil kesimpulan bahwa tidak ada perbedaan antara siswa laki-laki dan siswa perempuan pada variabel selfefficacy. Perbedaan persepsi mengenai iklim kelas antara siswa laki-laki dan siswa perempuan SMP Madania. Dari hasil perhitungan tersebut dapat dilihat bahwa nilai signifikansi variabel persepsi mengenai iklim kelas sebesar 0.730 (>0.025). Karena itu dapat diambil kesimpulan bahwa tidak ada perbedaan antara siswa laki-laki dan siswa perempuan pada variabel persepsi mengenai iklim kelas.

Perbedaan orientasi task antara siswa laki-laki dan siswa perempuan SMP Madania. Dari hasil perhitungan tersebut dapat dilihat bahwa nilai signifikansi variabel orientasi task sebesar 0.720 (>0.025). Karena itu dapat diambil kesimpulan bahwa tidak ada perbedaan antara siswa laki-laki dan siswa perempuan pada variabel orientasi task. Perbedaan orientasi ego self-enhancing antara siswa laki-laki dan siswa perempuan SMP Madania. Dari hasil perhitungan tersebut dapat dilihat bahwa nilai signifikansi variabel orientasi ego self-enhancing sebesar 0.289 (>0.025). Karena itu dapat diambil kesimpulan bahwa tidak ada perbedaan antara siswa laki-laki dan siswa perempuan pada variabel orientasi ego self-enhancing.

Perbedaan orientasi ego self-defeating antara siswa laki-laki dan siswa perempuan SMP Madania. Dari hasil perhitungan tersebut dapat dilihat bahwa nilai signifikansi variabel orientasi ego self-defeating sebesar 0.136 (>0.025). Karena itu dapat diambil kesimpulan bahwa tidak ada perbedaan iswa laki-laki dan siswa perempuan pada variabel orientasi ego self-defeating. Perbedaan orientasi work avoidance antara siswa laki-laki dan siswa perempuan SMP Madania. Dari hasil perhitungan tersebut dapat dilihat bahwa nilai signifikansi variabel orientasi work avoidance sebesar 0.272 (>0.025). Karena itu dapat diambil kesimpulan bahwa tidak ada perbedaan antara siswa lakilaki dan siswa perempuan pada variabel orientasi work avoidance.

\section{PENUTUP}

Berdasarkan hasil pengolahan dan analisis data penelitian yang telah dilakukan dapat disimpulkan bahwa tidak ada hubungan yang positif dan signifikan antara persepsi siswa mengenai iklim kelas dengan orientasi task dengan mengontrol self-efficacy. Tidak ada hubungan yang positif dan signifikan antara persepsi siswa mengenai iklim kelas dengan orientasi ego self-enhancing dengan mengontrol self-efficacy. Tidak ada hubungan yang negatif signifikan antara persepsi siswa mengenai iklim kelas dengan orientasi ego self-defeating dengan mengontrol self-efficacy.

Ada hubungan yang negatif dan signifikan antara persepsi siswa mengenai iklim kelas dengan orientasi work avoidance dengan mengontrol self-efficacy. Self-efficacy lebih banyak memberikan sumbangan pengaruh terhadap orientasi tujuan dibandingkan persepsi siswa mengenai iklim kelas. Tidak ada perbedaan antara siswa laki-laki dan siswa perempuan pada variabel persepsi mengenai iklim kelas, variabel self-efficacy, dan variabel orientasi tujuan (task, ego self-enhancing, ego selfdefeating, work avoidance)

Berdasarkan penelitian ini maka diketahui bahwa iklim kelas di sekolah Madania sedemikian rupa, dimana keadaan kelas diatur dengan sistem moving class, yaitu siswa yang berpindah ke ruang mata pelajaran bukan guru yang menetap, belum cukup memberi pengaruh terhadap orientasi task dan orientasi ego self-enhancing. Siswa belum dapat diarahkan untuk mengadopsi kedua orientasi tersebut. Hal ini menurut peneliti terjadi karena di Sekolah Madania tidak menerapkan sistem ranking, sehingga iklim kompetisi di Sekolah Madania belum cukup terlihat. Siswa di Sekolah Madania mendapatkan hasil ujian (raport) secara individu, dan dalam raportnya tidak dituliskan rankingnya. Hal ini memang 
dilakukan sekolah dengan maksud untuk tidak membeda-bedakan atau mengkotak-kotakan siswa. Seluruh siswa dikembangkan dan dinilai berdasarkan potensi dan kemampuannya masing-masing. Kebijakan sekolah ini dapat dilihat dari dua sisi yang berbeda. Sisi positifnya adalah siswa mendapatkan penanganan sesuai dengan potensi dan kemampuannya masing-masing, namun sisi negatifnya adalah kurang terciptanya iklim kompetisi diantara mereka, sehingga kurang mengarahkan siswa untuk mengadopsi orientasi task dan orientasi ego self-enhancing.

Sementara itu persepsi siswa mengenai iklim kelas tidak berhubungan terhadap orientasi ego self-defeating baik korelasi negatif maupun korelasi positif. Hal ini menurut peneliti terjadi karena walau orientasi ini negatif, namun siswa masih menunjukkan perilaku mau belajar. Siswa masih mau belajar walau tujuannya untuk menghindari terlihat bodoh atau dinilai negatif oleh orang lain, hanya saja usaha yang ditunjukkan siswa minim, sehingga secara statistik tidak terlihat korelasinya.

Penelitian ini juga menunjukkan bahwa ada korelasi negatif dan signifikan antara self-efficacy dan persepsi siswa mengenai iklim kelas. Hal ini sesuai dengan apa yang dikemukakan oleh Church et. al., (2001) yang mengatakan bahwa persepsi terhadap pengajaran tidak berkaitan dengan orientasi work avoidance karena siswa dengan orientasi ini tidak mempedulikan hal-hal yang terjadi di kelas, termasuk pengajaran yang diberikan oleh guru.

Hasil dari penelitian ini juga menunjukkan bahwa orientasi tujuan siswa lebih besar dipengaruhi oleh self-efficacy dari pada persepsi siswa mengenai iklim kelas terlihat dari nilai korelasi self-efficacy yang lebih besar dari pada persepsi siswa mengenai iklim kelas terhadap orientasi tujuan.

Dari penelitian ini peneliti menyarankan kepada pengelola pendidikan agar lebih memperhatikan kondisi emosi siswa untuk memperkuat self-efficacy mereka. Pengelola pendidikan juga perlu melakukan pelatihan-pelatihan guna meningkatkan self-efficacy mereka. Mengingat selfefficacy dapat mengarahkan siswa kepada orientasi tujuan yang positif, yaitu orientasi task dan orientasi self-enhancing. Bila orientasi tujuan siswa positif, maka pada gilirannya akan mengarahkan kepada pencapaian prestasi dalam pendidikan yang maksimal dan menghindari orientasi work avoidance.

\section{DAFTAR PUSTAKA}

Ames, C. (1992). Classrooms: goals, structures, and student motivation. Journal of Educational Psychology, 84, 261-271.

Ames, C. \& Archer, J., (1998). Motivation goal in the classroom: Student learning strategies and motivation process. Journal of Eeducational Psychology, 80, 260-267.

Bandura, A. (1986). Social foundations of thought and action: a social cognitive theory. New Jersey: Prentice Hall.

Bandura, A. (1994). Self-Efficacy. Dalam V.S. Ramaachaudran (Ed). Encyclopedia of human behavior (Vol. 4, hal. 71-81). New York: Academic Press.

Barron, KE. \& Harackiewicz, J.M. (2001). Achievement goals and optimal motivation: Testing multiple goal models. Journal of Educational Psychology, 80, 706-722.

Chaplin, J.P. (1999). Kamus Lengkap Psikologi. (Edisi 5). Jakarta : PT Raja Grafindo Persada. 
Chuch, M., Elliot, A., \& Gable, S. (2001). Perception of classroom environment, achievement goal, and achievement outcomes. Journal of educational Psychology, 93, 43-54.

Cote, J.E. \& Levine, C.G. (2000). Attitude versus aptitude: is intellegence or motivation more important for positif higher-educational outcomes? Journal of Adolescent Researh, 15, 58-80.

Entwistle, N. (1981). Styles of learning and teaching. New York: John Wiley \& Sons.

Harackiewicz, J.M. Barron, K.E. Carter, S.M., Lehto, A.T., \& Elliot, A.J.(1997). Predictor and consequences of achievement goals in the college classroom: maintaining interest and making the grade. Journal of Educational Psychology, 73, 1284-1295.

Harackiewicz, J. M., Barron, K.E., Tauer, J.M., Carter, S.M., \& Elliot, A.J. (2000). Short-term and long-term consequences of achievement goals: Predicting interest and performance overtime. Journal of Educational Psychology, 92, 316-330.

Jagacinski, C.M. \& Duda, J.L. (2001). A comparative analysis of contemporary achievement goal orientation measures. Educational and Psychological Measurement, 61, 1013-1039.

Matlin, M.W. (2002), Cognition (5th Ed) Singapore: Thomson Learning.

Maurer, TJ., \& Pierce. (1998). A Comparison of Likert Scale and Traditional Measures of SelfEfficacy. Juornal of Applied Psychology. 83 (2). 324-329.

McCombs, B. L. \& Whisler, J.S. (1997). The Learner-centered classroom and school. San Fransisco: Jossey-Bass Publishers.

Meece, J.L. \& Holt, K. (1993). A Pattern analysis of students achievement goals. Journal of Educational Psychology, 85, 582-590.

Pintrich,P.R. \& Schunk, D.H. (1996) Motivation in education: Theory, research, and Application. New Jersey: Prentice-Hall, Inc.

Ramsden, P. (1992). Learning to teach in higher education. London: Routledge, Chapman and Hall.

Stipek, D.J. (2000). Motivation to learn: integrating theory and practice (4th Ed). Singapore: Allyn and Bacon.

Skaalvik, Einar M. (1997). Self-Enhancing and Self-Defeating Ego Orientation: Relations With Task and Avoidance orientation, Achievement, Self-Perceptions, and Anxiety. Journal of Educational Psychology, vol. 89 No.1 p.71-81.

Webster, M. (1990) Webster's 9th New Collegiate Dictionary. Massachusetts: Meriam Webster.

Wilhite, (1990). Self-efficacy, locus of control, self assesment of memory ability and study activities as predictor of college course achievement, Journal of Educational Psychology, 82, 696-705.

Woolfolk, A.E. (2004). Educational Psychology (7th Ed). Singapore: Allyn and Bacon. 